\title{
Tubuh Sosial Siswi Madura: Studi Kasus Di SMPN 1 Labang
}

\author{
Naufalul Ihya' Ulumuddin ${ }^{1}$, Akbar Mawlana ${ }^{2}$ \\ ${ }^{1}$ Fakultas Ilmu Sosial Dan Hukum, Universitas Negeri Surabaya, Jl. Ketintang, Surabaya, 60213 \\ E-mail: naufalul.18031@mhs.unesa.ac.id \\ ${ }^{2}$ Fakultas Ilmu Sosial Dan Hukum, Universitas Negeri Surabaya, Jl. Ketintang, Surabaya, 60213 \\ E-mail:akbar.18002@mhs.unesa.ac.id
}

\begin{abstract}
Education and the body are closely related. School as a means of education does not only transfer knowledge to students, but also hones awareness of their bodies. However, in the field, it shows that Madurese female students who study in Madura do not realize that their bodies are the objects of power relations that operate through a hidden curriculum. This research tries to explain the cause. In order to obtain data about it, a case study approach, as a cluster of qualitative methods, was used in this field work. The data, which were mostly obtained from unstructured interviews, were then explained using social body studies. The results of this study indicate that the body as an object of power relations appears in the regulation of the use of the headscarf ("Jilbab")for Madurese female students, especially those who attend SMPN 1 Labang, Bangkalan. Thus, the public schools there seem to discipline Madurese female students as if they are undergoing a regular Islamic boarding school or madrasah education almost everyday life.
\end{abstract}

Keywords - : Social Body Studies; Education; MadureseFemale Students.

\section{PENDAHULUAN}

Kemanusian adalah nilai-nilai utama pendidikan. Pendidikan bukan pengajaran karena, pendidikan memikul tanggung jawab sebagai aksi penyadaran untuk humanisasi (Freire, 2001:120). Namun, proses pendidikan di sekolah selama ini masih menyimpan benih diskriminasi. Bentuk diskriminasi di sekolah yang sangat memprihatinkan adalah menyinggung identitas agama (Heryanto, 2019:71). Sehingga, agama sebagai objek yang tidak pernah netral di sekolah. Diskriminasi agama di sekolah ini sudah berlangsung lama, misalnya,di masa orde baru (orba), pemerintah pernah menerapkan kebijakan pelarangan penggunaan jilbab bagi siswi beragama Islam.

Hingga kini, persoalan diskirminasi agama tersebut masih terjadi di sekolah (Arief dan Husin,2019). Karena, kondisi sosial budaya di Indonesia pasca orbalebih berkutat pada nilai-nilaiIslamisme (Heryanto, 2019:74). Representasi nilai Islamisme tersebut berupa aturan yang mewajibkan siswi memakai jilbab dan ditopang kuasa simbolik yang melekat pada tubuh gurunya. Berdasarkan penelitian Putri (2018) menunjukkan bahwa melalui modal simbolik ini guru melakukan perintah dan pelarangan kepada para siswa dan siswi mereka. Kurikulum pendidikan nasional juga memberikan otoritas yang hampir absolut kepada guru untuk menentukan arah keberhasilan sistem pendidikan disekolah. Guru menjalankan peran sebagai pendidik berdasar pada kurikulum. Sehingga, kurikulum bukan sebatas petuntuk ideal sistem pendidikan, melainkan menjelma sebagai pengendali ideologi siswa dan siswi mereka di sekolah (Apple, 2004: 99).

Ideologi terselubungdalam kurikulum pendidikan tersebut membentuk dikotomi antara pantas dan tidak pantas. Dikotomi ini dibentuk oleh pengetahuan dan diproduksi melalui bahasa pihak berkuasa sehingga, bertendensi membentuk identitas (Udasmoro, 2020:7). Ketidakpantasan mungkin terjadi meluas berkat kuasa dominasi pemeluk agama di kawasan sekolah berada. Menurut Irwandi dan Tobroni (2020)bahwa relasi kuasa dalam masyarakat mayoritas beragama Islam akan membuat kewajiban berjilbab sebagaipendisiplinan bagi siswi muslim maupun non muslim yang kehidupan sehari-hari mereka tidak terbiasa menggunakan jilbab.

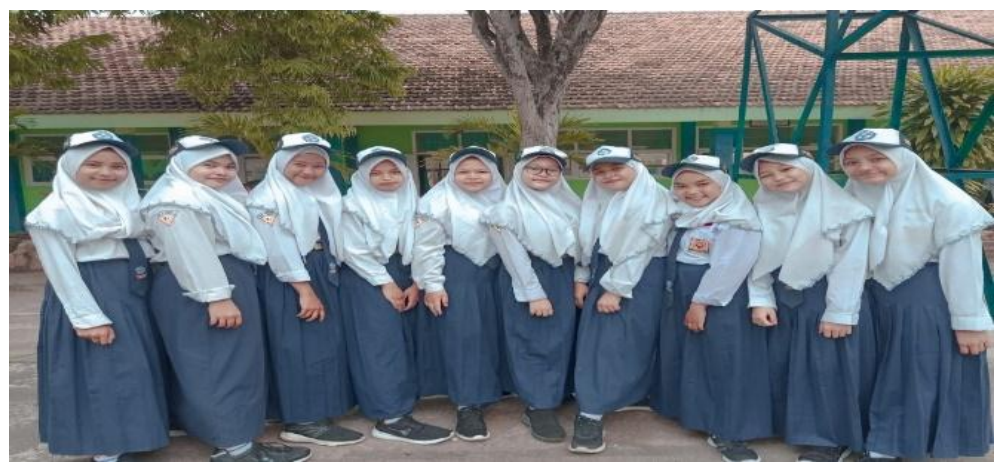

Gambar 1. Seragam Jilbab Siswi SMPN 1 Labang, Bangkalan (Sumber: Informan) 
Di SMPN (Sekolah Menengah Pertama Negeri) 1 Labang, kabupaten Bangkalan, penggunaan jilbab menjadi aturan wajib yang harus dipatuhi oleh para siswinya. Aturan sekolah ini berlaku sejak tahun 2010 dan para pelanggarnya akan mendapatkan sanksi dari guru, baik berupa teguran lisan kepada siswi maupun orang tua mereka. Kadangkala, teman-temannya ikut mencibir para siswi yang melanggar dengan bahasa 'kutukan' kecil. Kurikulum terselubung dengan memaksakan ideologi guru membuat para siswa dan siswi teralienasi dari kesadaran mereka sendiri (Apple, 2004:174). SMPN 1 Labang boleh jadi adalah sekolah menengah di Bangkalan yang mempelopori aturan berjilbab, baik kepada siswi maupun guru perempuannya. Padahal, sependek pengamatan peneliti selama hidup di Bangkalan ini belum pernah ada kewajiban seperti ini sebelumnya. Jika pun ada, tidak menjadi aturan tertulis di sekolah karena, sifatnya sebatas himbauan melalui obrolan biasa saja.Apalagi, berdasarkan pemerintah pusat bahwa berhak tidaknya para siswa dan siswi menggunakan atribut agama dalam institusi pendidikan berada di tangan orang tua, bukan sekolah (Thewe, 2021:1). Karean itu, fenomena ini menarik dikaji dari sudut pandang budaya penubuhan. Tubuh manusia yang seharusnya menjadi benteng terakhir otonomi pada akhirnya kehilangan kedaulatan dari tangan pemiliknya (Raditya, 2014). Atas dasar itulah, tulisan ini hendak mengulas lebih jauh tentang pendidikan penubuhan di sekolah tersebut.

\section{METODE PENELITIAN}

Penelitian ini menggunakan metode kualitatif. Penelitian kualitatif merupakan prosedur penelitian yang menghasilkan data deskripsi, baik berupa lisan ataupun tulisan atas perilaku yang dapat diamati (Moleong, 2000). Instrumen utamanya adalah peneliti dengan konsep dan pemahaman awal yang ada dalam kesadarannya. Tujuannya,berusaha memperoleh keterangan data atas kesadaran manusia dengan dimensi sosialnya (Giddens, 2010:5). Analisis metode kualitatifini bersifat induktif. Yakni, berangkat dari persoalan di tengah masyarakat kemudian dipadukan dengan konsep teoritik yang dianggap relevan membaca datanya. Dengan kata lain, penelitian kualitatif mengedepankan pemaknaan khusus atas realitas sosial (Sadewo, 2016). Penelitian ini memakai pendekatan studi kasus dengan memilih lokasi berskala kecil, yakni, di SMPN 1 Labang yang secara geografis dan administratif terletak di desa Pangpong, Kecamatan Labang, Bangkalan.

Penelitian ini dilakukan di masa pandemi Covid-19, sehingga, akses memperoleh data sangat terbatas sekali. Terdapat beberapa prosedur kesehatan yang harus dijalani jika hendak wawancara langsung ke sekolah. Terlebih, sebagian siswi sekolah ini sulit ditemui di sekolah karena, masih memakai pengajaran daring. Beberapa di antara informan tidak mau diwawancarai langsung, sehingga penggunaan media sosial melalui WhatsApp bisa sedikit membantu, sekalipun, kendala terbesarnya adalah keabsahan data dan hubungan empatik yang tidak mudah terbentuk antara peneliti dengan informannya.

\section{III.HASIL DAN PEMBAHASAN}

\section{A. Sekolah Negeri SerasaSekolah Agama}

SMPN 1 Labang merupakan salah satu dari empat sekolah menengah pertama berstatus "negeri" yang terletak di kecamatan Labang. SMPN1 Labang tergolong sekolah favorit yang ada di tingkat kecamatan. Dapat terlihat dari jumlah penerimaan siswa baru di tiga tahun terakhir. Di tahun 2018, terdapat 267 siswa baru. Pada tahun 2019 dan 2020,jumlah siswa barunya sebanyak 247 siswa.Setiap tahun, rata-rata sekitar 770-780 siswa bersekolah di SMPN 1 Labang. Angka ini terbilang tinggi dibandingkan tiga sekolah lain sejenis di kecamatan Labang yang bisamenampung sekitar 400 - 500-an siswa.

Ada beberapa alasan dari orang tua untuk menyekolahkan anak mereka di SMP Negeri 1 Labang. Pertama, orang tua siswa belakangan ini merasa bahwa masuk sekolah negeri memiliki gengsi tersendiri daripada masuk ke sekolah swasta berbasis agama. Terlebih lagi, di sekolah negeri juga diajarkan pendidikan agama secara umum. Sehingga, orang tua tidak perlu khawatir akan kehilangan pendidikan agama bagi anaknya. Kedua, sekolah negeri favorit dianggap lebih menjamin masa depan alumninya, terutama, saat melanjutkan ke jenjang pendidikan di atasnya. Ketiga, sekolah negeri dianggap sekolah umum yang menciptakansuasana hidup heterogen dan mengajarkan nilai-nilai toleransi(Rifai, 2007).

Namun, kuatnya Islamisme masyarakat Labangmenembus dinding pendidikan. Termasuk, sekolah negeri sekalipun. Islamisme merupakan ajaran Islam fundamentalis yang berusah keras melarang segala bentuk kehidupan apa pun yang bertentangan dengan ajaran Al-Quran (Heryanto, 2011). Islamisme di sekolah membuat siswa terpenjara dalam kesadaran magis. Kesadaran magis menanamkan benih penindasan, karena, mengajarkan manusia pada sikap fatalism dan sulit mengungkap kesewenang-wenangan struktur sosial di masyarakat (Freire, 2001:63).Sekolah negeri di kecamatan Labangumumnya secara budaya tampaknya hampir mirip dengan sekolah berbasis agama. Sekolahnya memiliki kebiasan rutin, layaknya rutinitas pendidikan model pesantren maupun madrasah, seperti mengaji, ibadah berjemaah, duduk terpisah laki-laki dan perempuan, dan 'mewajibkan'pakaian muslimah bagi siswinya setiap hari.

Kultur agama mayoritas orang Madura yang masuk ke lingkungan sekolah ini merepresentasikan adanya kurikulum tersembunyi. Kurikulum tersembunyidisampaikan oleh para pendidik yang menjadi bagian tidak terpisahkan dari struktur sosial mereka (Giroux, 1983:29). Kurikulum ini dapat menghasilkan sekaligus melanggengkan budaya agama mayoritas dan terkesan membatasi, bahkan, mungkin saja meremehkan penganut agama minoritas. Peserta didik dipaksa patuh terhadap peraturan yang berlaku. Hal ini menurut Appel (2004) menjadi hegemoni baru dengan memakai kekuasaan tersembunyi dalam penentuan kebijakan pendidikan.Dehumanisasi pendidikan mudah terjadi apabila kelompok masyarakat yang tidak berdaya dari aspek struktur sosial, ekonomi, dan politik dibiarkan larut dalam budaya bisu (Freire, 2001:120). Menurut salah seorang guru yang pernah penulis wawancarai mengatakan bahwa jilbab dengan pakaian pelengkapnya bagi para siswi di sekolah menjauhkan 
Website : http://sosial.unmermadiun.ac.id/index.php/sosial

mereka dari pandangan maksiat lelaki. Jika demikian, bukankah harusnya yang ditutup rapat-rapat adalah pandangan dan isi kepala laki-laki yang liar ? Pertanyaan balik dari penulis ini seakan membuatnya kebakaran jenggot. Atas dasar ini, konsep tubuh berelasi dengan fantasi terbesar adalah ide mengenai tubuh sosial yang dibentuk oleh universalitas kehendak berkuasa(Foucault, 2017:74).

\section{B. Pendidikan Agama yang Menubuh}

Tubuh menurut Foucault berkaitan erat dengan kuasa(Foucault, 2017:73). Tubuhdalam relasi kuasa nyaris lepas dari kuasa pemiliknya (Budiawan, 2015:65). Kurikulum tersembunyi pendidikan yang berkembang di SMP Negeri 1 Labang menunjukkan bahwa tubuh siswi menjadi objek kuasa agama. Agama sebagai suatu dogma dengan ancaman hukuman akhiratnya memaksa siswi Madura ini menjadikan tubuhnya patuh pada nilai-nilai penggunaan pakaian muslimah melalui pendidikan agama. Dari sini terlihat bahwa kurikulum sebagai pengendali ideologi (Apple, 2004:99).

Ideologi agama dominan di Madura mengendalikan tubuh siswi dalam kehidupan sosialnya. Kuasa tubuh atas siswi diproduksi melalui penentuan seragam sekolah sejak mereka pertama kali diterima di sekolah. Konon, sebelum tahun 2010,SMPN 1 Labang tidak memberikan batasan dalam hal penggunaan seragam beratribut keagamaan ini. Kala itu, siswi yang tidak berjilbab ataumenggunakan rok mini menjadi hal yang biasa terlihat di sekolah ini.Menurut Foucault (1978) kuasa atas tubuh manusia lebih banyak bekerja di dalam regulasi. Baik tertulis ataupun tidak.

\section{Tubuh dan Aurat}

Tubuh merupakan sebuah entitas yang tidak bisa lepas dari dua hal yakni, pribadi dan publik. Tubuh menjadi milik pribadi ketika berada di ruang privat, dan tubuh menjadi milik sosial ketika berada di ruang publik. Keberadaannya di ruang publik inilah yang disebut tubuh sosial. Tubuh yang tunduk terhadap aturan-aturan sosial (Raditya, 2014). Lingkungan sosial budaya masyarakat sekitar SMP Negeri 1 Labang memaksa siswi di sekolah tidak otonom terhadap tubuhnya. Tubuhnya dianggap sebagai aurat yang dalam ajaran pendidikan agama merupakan hal yang haram untuk diperlihatkan. Bagian tubuh perempuan dianggap sensitif dan mengundang hasrat dari lawan jenis. Konsep aurat pada tubuh siswiMadura ini akhirnya berkutat pada budaya lama dan dikendalikan oleh dogma agama. Menurut Derrida dalam Barker(2006) menjelaskan makna budaya tidak mengacu pada objek independen yang berpotensi untuk berkembang tanpa batas. Pemaknaan atas tubuh perempuan dapat berubah karena perubahan masyarakat terhadap tubuh sosialnya (Barker, 2006:96-97). Secara sosiologis, tubuh terserak-serak dalam permainan tanda-tanda budaya. Melalui budaya, semisal media massa dan bahasa, pengetahuan dan makna atas tubuh terus menerus diproduksi dan direproduksi, sehingga, terbentuk identitas tubuh yang berbeda-beda dari satu masyarakat ke masyarakat yang lain(Udasmoro, 2020:32). Berdasarkan hal ini maka, tubuh siswi yang bersekolah di Madura menjadikannya objek wacana mengenai keauratan tubuhnya.

\section{IV.KESIMPULAN}

Siswi yang bersekolah di Madura sulit mendapatkan pendidikan kritis, humanis, apalagi, menubuh. Karena, tubuh sosialnya terlepas dari otonomidirinya sebagai manusia yang harusnya dimanusiawikan.Sekolah umum yang berstatus "negeri" akhirakhir ini di Madura, terutama, di Bangkalan, mengalami perubahan makna. Nilai-nilai kemanusiaan dan toleransi terhadap penghormatan terhadap kedaulatan tubuh para siswinya berangsur-angsur menipis. Mereka tenggelam ke dalam kesadaran magis yang fatalistik. Sehingga, operasi kuasa yang bekerja melalui kurikulum tersembunyi dalam sistem pendidikannya tidak pernah, atau mungkin belum, memposisikan siswi sebagai subjek pendidikan yang sadar akan persoalan struktur sosial yang telah lama membungkamnya.

\section{UCAPAN TERIMA KASIH}

Tulisan ini masih jauh dari sempurna. Namun, belajar pendidikan yang menubuh akan selalu diupayakan. Karena itu, ucapan terima kasih disampaikan kepada Tuhan Yang Maha Esa atas segala rahmat dan ridhoNya. Berikutnya, terima kasih kepada Dr. Ardhie Raditya yang bersedia mendampingi penelitian ini hingga terwujud ke dalam tulisan yang 'eksentrik' ini . Terima kasih juga kepada para informan, baik siswi maupun guru, yang berkenan meluangkan waktu untuk berbincang-bincang sejenak mengenai tubuh, agama, dan kurikulum pendidikan di sekolahnya. Terakhir, kepada segenap pengajar di Sosiologi Unesa, dan tim redaksi jurnal ini, yang telah memperkenankan penulis mempublikasikan penelitian berbasis lapangan di tengah pandemi ini.

\section{VI.DAFTAR PUSTAKA}

Atmoko, T. Prasetyo Hadi. 2014. Strategi Pengembangan Potensi Desa Wisata Brajan Kabupaten Sleman. Jurnal Media Wisata Volume 12, Nomor 2, November 2014.

Apple, M. W. (2004). Ideology and Curriculum. Routledge Falmer.

Arief, M. I., \& Husin, G. M. I. (2019). Agama Dan Sistem Pendidikan Nasional (Kasus Pelarangan Jilbab Di Sekolah). Darul Ulum: Jurnal Ilmiah ..., 10. http://ejournal.stitdukotabaru.ac.id/index.php/darululum/article/view/36

Barker, C. (2006). Culture Studies: Teori dan Praktik (H. Purwanto \& Nurhadi (eds.); Terjemahan). Kreasi Wacana.

Budiawan, Aryamami, D., Junaedi, F., Raditya, A., Maimunah, Sosiawan, E. A., Yuwon, A. I., Wijaya, B. S., Narwaya, S. T. G., \& Faisal, A. (2015). Media (Baru), Tubuh, dan Ruang Publik (Budiawan (ed.); 1st ed.). Jalasutra.

Foucault, M. (1978). The Archaeology of PowerDiscipline and Punish: The Birth of the Prison. In Contemporary Sociology (Vol. 7, Issue 5). https://doi.org/10.2307/2065008 
Website : http://sosial.unmermadiun.ac.id/index.php/sosial

Foucault, M. (2017). Power/Knowledge: Wacana Kuasa/Pengetahuan (T. Setiawan, Sufianto, \& Dkk (eds.)). Narasi-Pustaka Promothea.

Freire, P. (2001). Pedagogi Pengharapan, Menghayati Kembali Pendidikan Kaum Tertindas. Kanisius.

Giddens, A. (2010). Metode Sosiologi: Kaidah-Kaidah Baru (1st ed.). Pustaka Pelajar.

Giroux, H. (1983). The Hidden Curriculum and Moral Education.

Heryanto, A. (2019). IDENTITAS DAN KENIKMATAN: Politik Budaya Layar Indonesia (Kelima). Kepustakaan Populer Gramedia.

Irwandi, P., \& Tobroni, F. (2020). Tinjauan Nalar Relasi Kuasa dalam Aturan Berjilbab di Solok dan Pesisir Selatan. Jurnal Kajian Perempuan, Gender, 1(6), 103-117. http://journal.iain-ternate.ac.id/index.php/alwardah/article/view/248

Moleong, L. J. (2000). Metodologi Penelitian Kualitatif. Remaja Rosda.

Putri, R. O. (2018). Praktek Kekerasan Simbolik (Relasi Guru dan Peserta didik dalam Pendidikan Islam). Millah: Jurnal Studi Agama, 17(2), 319-336.

Raditya, A. (2014). Sosiologi Tubuh: Membentang Teori di Ranah Aplikasi (M. Mudzakkir (ed.); 1st ed.). Kaukaba Dipantara.

Rifai, M. A. (2007). Manusia Madura: Pembawaan, Perilaku, Etos Kerja, Penampilan, dan Pandangan Hidupnya seperti dicritakan Pribahasanya. Pilar Media.

Sadewo, F. S. (2016). Meneliti Itu Mudah. In M. Legowo (Ed.), UNESA University Press (Issue 9). Unesa University Press. https://doi.org/10.1017/CBO9781107415324.004

Thewe, S. (2021). SKB 3 Menteri Tentang Pakaian Seragam \& Atribut Sekolah Tahun 2021 - Sinau-thewe. Sinau Thewe.Com. https://www.sinauthewe.com/2021/02/skb-3-menteri-tentang-pakaian-seragam.html

Udasmoro, W. (2020). Gerak Kuasa:Politik Wacana, Identitas, dan Ruang / Waktu dalam Bingkai Kajian Budaya dan Media. Gramedia. 